\title{
Konseling Individu dengan Teknik Modeling untuk Meningkatkan Kekuatan Karakter Kesederhanaan
}

\author{
Cucu Arumsari \\ Universitas Muhammadiyah Tasikmalaya \\ Email: cucu.arumsari@umtas.ac.id
}

\begin{abstract}
:
Individual counseling with modeling techniques has been proven effective in increasing the strength of the character of temprence. Clients were very active in participating in each counseling session. Researchers can observe clients clearly on each counseling process. This study used qualitative method with types of grounded research and descriptive tchnique so that the analysis is very clear and detailed. The three counselees clients who conducted individual counseling can be analyzed experiencing an increasement in the power of temprence character. Research was conducted on three counselees, the results of the study proved effective to develop the strength of the character of temperance, it can be seen that there is evidence first counselee are able to be better at people who hurt them, able to make friends with everyone, be able to do tasks more timely and can control emotions more. second counselee also get better by being able to appreciate their friends as well as third counselee who can control emotions more when find unpleasant situations.
\end{abstract}

Keyword: Counseling, Temprence, Modeling

Received August 04, 2018; Revised September 25, 2018; Accepted October 01, 2018

How to Cite: Arumsari, C. (2018). Konseling Individu dengan Teknik Modeling untuk Meningkatkan Kekuatan Karakter Kesederhanaan. JKI (Jurnal Konseling Indonesia), 4(1), 1-15.

\section{PENDAHULUAN}

Kekuatan karakter merupakan ramuan psikologis (psychological inggrediens) yang merepresentasikan nilai-nilai kebajikan (virtues) yang bersumber dari pemikiran-pemikiran religius (religious thinkers) dan philosofi moral (moral philoshopers) (Peterson et al., 2004). Kekuatan karakter kesederhanaan adalah kekuatan yang melindungi dari kelebihan (Mamarodi, 2015). Ciri atau komponen kekuatan temperance (Peterson et al., 2004) adalah sebagai berikut: (1) Forgiveness and Mercy atau pengampunan dan belas kasihan; (2) Humality atau kerendahan hati; (3) Prudence atau Kebijaksanaan; (4) Self-regulation atau kontrol diri.

Kekuatan karakter kesederhanaan merupakan bagian dari teori kekuatan karakter dan kebajikan (Said, 2016). Teori ini sangat sesuai digunakan dalam layanan bimbingan dan konseling. Bagi guru, orang tua ataupun individu dari teori ini bisa menyadarkan kembali, harus bijaksana dalam menghadapi setiap masalah, belum tentu individu yang bermasalah itu tidak bisa berhasil, dan belum tentu individu yang berprestasi 
seterusnya berhasil, sehingga semuanya perlu bimbingan dengan fokus terhadap hal-hal positif yang ada dalam diri individu tersebut (Arumsari, 2018).

Struktur kekuatan-kekuatan dikalangan remaja dan hubungannya dengan kesejahteraan telah sedikit menerima perhatian sistematis (Toner et al., 2012). Kesederhanaan adalah kebajikan glamor paling ekspresi kontras langsung dengan budaya konsumerisme, dan ditekankan untuk menemukan sebuah film yang menggambarkan karakter yang telah menyerahkan implus dan terlibat dalam merokok, minum, membius, makan berlebihan, seks komplusif atau perilaku agresif (Niemiec et al., 2009).

Dalam rancangan penelitian ini aspek-aspek kesederhanaan tersebut diarahkan secara sistematis dalam konseling individu dengan teknik modeling simbolis. Konseling adalah upaya bantuan yang diberikan seorang pembimbing yang terlatih dan berpengalaman, terhadap individu-individu yang membutuhkannya, agar individu tersebut berkembang potensinya secara optimal, mampu mengatasi masalahnya, dan mempu menyesuiakan diri terhadap lingkungan (Willis, 2010).

Dengan modeling simbolis peneliti bisa menyesuaikan memilih model sesuai dengan keadaan dan kerekter konseli. modeling simbolis harus mempertimbangkan unsur-unsur berikut; karaktersistik klien, perilaku tujuan yang akan didemonstrasikan atau dimodelkan, sarana yang digunakan, isi tampilan dan pengujian model (Nursalim, 2005).

\section{METODE PENELITIAN}

Penelitian ini terdiri dari 3 (tiga) subyek penelitian yang memiliki kekutan karakter rendah yang terdiri dari konseli JT, DN dan SH. Instrumen penelelitian menggunakan instrumen kekuatan karakter kesederhanaan yang dikembangkan peneliti dari teori kekuatan karakter kesederhanaan.

Analisis data menggunakan naratif deskriptip dengan menjelaskan penggunaan konselin individu teknik modelling untuk meningkatkan kekutan karakter kesederhanaan. Metode analisis data dilakukan secara deskriptif, yaitu melalui, fenomena yag muncul selama penelitian dicatat, dikumpulkan, direduksi sehingga mendapatkan informasi yang cermat mengenai variabel penelitian .

Menurut Best (Sukardi, 2003) penelitian deskriptif merupakan metode penelitian yang berusaha menggambarkan dan menginterpretasi objek sesuai dengan apa adanya. Penelitian deskriptif (descriptive research) adalah suatu metode penelitian yang ditujukan untuk menggambarkan fenomena-fenomena yang ada yang berlangsung pada saat ini atau saat yang lampau (Creswell et al., 2017). Penggambaran kondisi bisa individual atau kelompok (Sa'ud, 2007).

\section{HASIL}

Proses konseling individu dengan teknik modeling untuk meningkatkan kekuatan karakter kesederhanaan dilaksanakan selama satu minggu sekali. Diakhir konseling, konseli diberikan lembar kerja yang harus dikerjakan selama satu minggu.

\section{Kasus Konseli JT}

Sesi konseling terhadap konseli JT dilakukan sebanyak empat sesi. Sesi konseling yang sudah dilaksanakan adalah sebagai berikut, sesi pertama dilaksanakan tanggal 05 Maret 2015, konseling dilakukan diruang guru. Pada sesi ini kegiatan yang dilaksanakan adalah pembangunan hubungan akrab, mendiskusikan tujuan dan agenda konseling. Hal ini penting agar konseli mengikuti sesi konseling tanpa rekayasa berbicara maupun bertindak. Tujuan yang ingin dicapai dalam sesi ini adalah membangun hubungan yang akrab dan positif, serta menjelaskan intervensi kepada konseli dan kemampuan yang akan diperoleh konseli.

Konselor memulai sesi konseling menanyakan kabar, "bagaimana kabarnya teh JT"? konseli menjawab, "baik teh". Setelah itu konselor langsung ke langkah I yaitu rasional atau atensi dengan menjelaskan tujuan dari konseling ini adalah untuk mengembangkan kekuatan karakter kesederhanaan dalam aspek pengampunan dan belas kasihan, menjelaskan prosedur konseling dengan teknik modeling simbolis dan media yang akan digunakan dalam proses konseling adalah video. Setelah itu konselor bertanya kepada konseli "masalah apa yang kira-kira teteh miliki yang bisa diceritakan kepada saya?". Konseli berfikir sebentar terus dia bercerita "waktu SMP saya punya sahabat, dia anak kepala sekolah teh, entah kenapa tiba-tiba dia menjauhi saya", konselor bertanya "teteh sudah cari tahu belum kenapa dia menjauhi teteh?", konseli menjawab "kata teman-teman sih dia punya prasangka saya mau menjauhkan dia dari cowoknya, karena saya dekat juga sama cowoknya", konselor bertanya lagi "oh berarti dia cemburu teh?" konseli menjawab "hehehehe iya 
mungkin", konselor bertanya lagi "teteh suka tidak sama cowok temen teteh?" konseli menjawab "ih engga, saya cuma temenan saja teh, setelah ada masalah dengan ceweknya, sayapun menjauh dari cowoknya". Untuk selanjutnya konselor bertanya apa penyebab konseli susah melupakan kesalahan temannya, konseli menjawab "selain saya kurang enak dengan sikap dia yang tiba-tiba menjauhi saya, yang kedua karena omongan mamahnya", konselor bertanya "maksud teteh bagaimana?" konseli menjawab, "gini teh mamah diakan suka bikin kue, nah ibu aku itu mau pesen kue ke mamahnya, eh malah mamahnya bilang minta anakmu saja yang bikin kue, jangan pesan ke sini, itu berartikan dia sampai cerita ke orangtuanya, dan itu tidak sopan bicara seperti itu ke ibu saya mamahnya itu". Konselor selanjutnya bertanya, "terus selanjutnya gimana hubungan teteh dengan sahabat teteh?", konseli menjawab, "sampai lulus SMP saya dengan dia jadi ga deket teh", konselor bertanya lagi "tapi teman teteh itu sama cowoknya sampai lulus tidak putus?". Konseli menjawab engga teh, terus konselor bertanya apa yang membuat konseli tidak ingin mengampuni temannya, konseli menjawab "malas saja".

Selanjutnya konselor masih bertanya apakah konseli mempunyai masalah yang sulit mengampuni orang lain konseli bercerita lagi, dia di bandung tinggal bersama tantenya, tantenya dirumah seakan tidak ada masalah, setiap bulan juga tantenya juga suka dikirim uang 2-3 juta untuk hidup JT dan biaya sekolah. Konseli bercerita "pernah pas pembagian raport tante saya datang ke sekolah untuk mewakili ngambil rapor, saya disuruh pulang duluan, sayapun pulang karena mau bantu bibi jaga warung dirumah, tante saya pulang dianterin teman saya, dirumah tante saya bergaya tidak ada apa-apa, tapi pas saya ke sekolah saya diceritain teman saya, kalau tante saya itu bilang ke guru kalau saya tidak suka dikirim uang oleh orang tua saya sehingga keuangan sekolah nunggak, saya tidak tahu mana yang benar, tapi setelah itu saya jadi tidak nyaman dekat tante saya", konselor bertanya "apakah teteh tidak bertanya yang sebenarnya ke tante, apa memang beliau bicara seperti itu atau tidak?", konseli menjawab "engga ah nanti takut rame, saya juga tidak bilang ke ibu sama bapak, takut mereka kepikiran", selanjutnya konselor bertanya apakah ada yang mau disampaikan lagi sebelum kita lanjutkan ke sesi selanjutnya, konseli menjawab sementara belum ada yang ingin disampaikan lagi.

Langkah II konselor pemberian contoh modeling atau retensi, konselor menjelaskan modeling simbolis yang akan ditampilkan hari ini adalah video, yang ada kaitannya dengan pengampunan, konselor mempersilahkan terlebih dahulu konseli memperhatikan video, setelah videonya selesai ditonton, konselor meminta konseli menyebutkan makna dari video yang dilihatnya, konseli dapat melihat anak yang terus dimusuhi oleh temannya tapi dia tidak membelas dendam, dia menangis tetapi juga tidak diam saja, dia berusaha cara yang lain agar bisa diterima oleh orang lain yaitu dengan sama-sama bisa berprestasi dalam bidang musik yang menjadi mimpi dan cita-citanya dari dulu, anak yang disiksa itu tidak terpuruk tapi menjadi orang yang lebih berhasil. Selanjutnya konselor menjelaskan, konseli tidak usah melupakan kesalahan-kesalahan orang yang sudah membuatnya kesal, tapi diusahakan tidak mempunyai dendam, tetapi dari setiap masalah yang sudah terjadi bisa diambil hikmahnya, dan konseli bisa menjadi lebih baik, lebih baik dalam bertindak pada orang yang pernah membuat kesal ataupun lebih baik dalam membawa diri dalam arti kita harus lebih berprestasi mengembangkan potensi konseli, jangan terpuruk memikirkan kesalahan orang lain kepada konseli dan malah lupa dengan potensi konseli yang harus dikembangkan, konselor bertanya apakah ada pertanyaan sebelum melanjutkan ke langkah tiga, konseli menjawab sudah cukup jelas dan tidak ada pertanyaan.

Langkah III latihan atau reproduksi motor, konselor menjelaskan kalau langkah ketiga ini adalah latihan untuk mengampuni kesalahan orang, dapat diambil kesimpulan kalau konseli sulit mengampuni orang yang berbuat salah pada dirinya, karena dia tidak mau untuk meluruskan masalah atau mengklarifikasinya, sehingga dia memilih untuk menduga-duga dan menghindar dengan orang yang sedang berkonflik dengan dirinya. Konselor meminta konselor berpura-pura menganggapnya teman yang sedang bermusuhan saat SMP, dan konselor meminta konseli bertanya kepada temannya dia memusuhinya, konselor "teh JT, mari kita coba kita pura-pura teman sebaya, saya teman teteh waktu SMP, kita ada di kelas dalam keadaan istirahat, silahkan teteh hampiri teman teteh dan sampaikan apa yang ingin teteh sampaikan", konseli berkata "saya mungkin mau bertanya, aku tidak nyaman selama ini kita menjadi jauh, apa penyebab kamu menjadi memusuhi aku?", konselor "bagus teh coba bayangkan teteh terus mengatakan kata-kata yang sopan untuk mengoreksi masalah yang terjadi, sampai teteh merasa nyaman, boleh dengan kata-kata lain. Teteh juga bisa membayangkan apa yang akan dikatakan dia kepada teteh, dan teteh sudah punya bayangan untuk menjelaskan atau menjawab dengan sangat baik dan sopan tanpa emosi", konselipun menyetujuinya, selian konseli membayangkan apa yang akan dikatakan, konselor 
meminta konseli membayangkan apa yang dia akan perbuat. Setelah kata-katanya tampak wajar, konselor meminta konseli berhenti dan bertanya bagaimana perasaannya setelah berlatih berbicara dan membayangkan apa yang akan terjadi, konseli mnyampaikan dia menjadi lebih tenang, dan dia siap menerima apapun yang terjadi, kerena memang dia merasa tidak bersalah, dan bersedia bersikap lebih baik pada temannya.

Langkah IV pekerjaan rumah atau motivasi, konseli diminta mengulangi modeling dan mempraktikan yang dirasakan sulit, terutama konseli JT ini merasa tidak nyaman dengan tantenya yang serumah, konseli bisa mempraktekan komunikasi yang baik dan mengampuni kesalahan tantenya. Selain itu kegiatan mengampuni dan belas kasihan lainnya kejadian sehari-hari yang konseli JT lakukan. Ringkasan membahas pekerjaan rumah, setelah satu minggu sebelum konselor melakukan konseling sesi ke dua, konselor menanyakan pekerjaan rumahnya, konseli meberikannya dan kami mendiskusikannya, konseli menyampaikan telah mengampuni teman sebangku yang lupa membawa buku tugasnya, konseli mengampuni adiknya yang setiap hari membuatnya kesal, konseli juga bercerita dia memberikan minum anak kecil yatim piatu yang tinggal bersama dengan neneknya sebagai mengaplikasikan belas kasihan, konseli juga mengampuni teman yang sekelas yang memusuhi, konseli juga tidak jajan uang disakunya Rp. 3000.000 diberikan kepada kakek seorang pengemis, selanjutnya konselor bertanya bagaimana perasaan dan sikap konseli kepada tantenya, walaupun dia belum berani bertanya apa yang terjadi tapi konseli sudah mengampuni dan mau mencoba bersikap biasa saja dengan tantenya dalam pekerjaan rumahnya konseli menuliskan kadang dirumah suka dimarahi tantenya, tapi konseli menganggap hal itu masih bisa diampuni karena menganggap tantenya melakukan itu untuk mengingatkannya.

Sesi kedua dilaksanakan pada tanggal 13 Maret 2015 di ruang guru. Konselor menanyakan kabar JT, "bagaimana kabarnya teh sehat?", konseli menjawab "sehat teh". Sesi dimulai dengan melakukan evaluasi terhadap sesi sebelumnya yang sduah dijelaskan diparagraf sebelumnya. Selanjutnya ke langkah pertama rasional atau atensi, konselor menjelaskan konseling pertemuan ini akan mengguanakan media biografi para tokoh tapi sebelum sesi konseling dilanjutkan, konselor bertanya masalah apa saja yang dihadapi konseli selama ini. Konseli menjelaskan "saya kadang suka banding-bandingin diri saya dengan orang lain, itu kadang membuat masalah buat diri saya sendiri", konselor bertanya "banding-bandingin dalam hal positif atau negatif?", konseli menjawab "dua-duanya teh, kadang-kadang dalam hal negatif maupun positif saya", konselor bertanya "contohnya apa?", konseli "ya banyak, contohnya aku itu kadang diejek, kadang dalam hati suka bandingin dia yang ngejek dengan aku", konselor "oh iya saya mengerti".

Selanjutnya langkah kedua pemberian contoh modeling atau retensi, konselor memberikan biografi orang yang berhasil salah satu yang mempengaruhinya adalah kerendahan hatinya, seperti tokoh Ir. H. Joko Widodo, Prof. Dr. H. Bacharuddin Habibie dan pemain bola Chambers. Setelah konseli membaca konselor bertanya makna apa yang bisa diambil dari biografi yang sudah dibaca, konseli menjawab "orang-orang tadi berhasil, dari bawah mereka tidak langsung jadi berhasil, awalnya mereka orang biasa-biasa saja", konselor membenarkan dan meminta konseli juga demikian apapun yang kita miliki supaya tidak menyombongkan diri karena sudah terbukti orang yang rendah hati banyak orang yang menolong. Selanjutnya konselor bertanya "apa sekarang yang akan teteh lakukan setelah mengetahui manfaat rendah hati?", konseli mejawab "saya akan lebih instropeksi diri", konselor "bagus teh, coba kalau ada akat-kata orang yang kurang menyenagkan tanya pada diri teteh itu benar atau tidak, tanpa merasa lebih baik", konseli "baik teh".

Langkah ketiga latihan atau reproduksi motor. "baiklah teh sekarang kita latihan, pura-puranya saya adalah teman teteh, mengatakan heh JT kamu itu hitam judes lagi, apa yang akan teteh lakukan dan katakana?", konseli berpikir sebentar lalu berkata "apakah benar? Walaupun penilaian kamu seperti itu tolong jangan bilang seperti itu sama aku, karena aku tidak nyaman", konselor "bagus teh,mungkin teteh juga bisa menambahkan dengan, menanyakan bagaimana teman teteh bisa mengatakan itu, itu sebagai bahan evaluasi teteh", konseli "oh iya baik teh".

Langkah keempat pekerjaan rumah/ motivasi, konselor meminta konseli mengerjakan lembar tugas selama seminggu, dan menuliskan apa saja yang sduah konseli lakukan untuk menjadi lebih rendah hati. Ringkasan dan evaluasi setelah sseminggu konselor dan konseli bertemu lagi untuk mendiskusikan hasil pekerjaan rumahnya, dari hasil pekerjaan rumahnya konseli memaparkan "saya sekarang lebih supel dengan teman-teman berusaha bisa lebih bergaul dengan semua teman dan juga saya sekarang lebih bisa mendengarkan atau menerima nasihat orang tua" konselor memberikan penghargaan dengan pujian dan meberikan penguatan agar konseli terus mengembangkan sifat rendah hatinya. karakter kesederhanaan, konselor menanyakan perubahan yang dirasakan oleh konseli setelah melaksanakan tiga sesi konseling. Konseli menjelaskan bahwa perasaan konseli 
senang karena bisa melihat inspirasi-inspirasi dan ada beberapa perubahan dalam kegiatan sehariharinya karena ingat dengan tampilan yang sudah diberikan, contohnya terus bersemangat belajar, karena buktinya ada juga yang berhasil walaupun dari keluarga biasa-biasa saja karena tekun dan tidak gengsi, sekarang konseli ke tantenya sudah mengampuni dan ke teman-teman lebih bisa dikurangi untuk marah-marahnya.

Sesi konseling ketiga tanggal 20 Maret 2015 di ruang guru. Sesi dimulai dengan menanyakan kabar "bagaimana kabarnya teh, sehatkan? Ko kaya lagi sakit?" konseli menjawab "baik teh, engga gak apa-apa kok hehehe". Setelah itu peneliti menanyakan mengenai lembar kerja yang telah dikerjakan, konselipun menceritakan apa yang sudah dia lakukan yang sudah dijelaskan diparagraf sebelumnya. Pada sesi kedua ini langkah I (pertama) rasional/ atensi yang didalamnya terdapat instruksi, yaitu konselor menjelaskan konseling teknik modeling simbolis hari ini akan menggunakan media film tentang kisah orang yang bisa berhasil karena kebijaksanaannya, konselor juga menjelaskan langkah atau tahapan yang akan dilakukan dalam konseling sama dengan konseling pertemuan sebelumnya, selanjutnya konselor menanyakan kesiapan konseli dan konselipun menyatakan sudah siap. Sebelum melanjutkan ke langkah kedua konselor bertanya apakah konseli tahu apa itu kebijaksanaan, konseli bilang tahu, tapi susah mengungkapkannya, konselorpun menjelaskan secara singkat kalau kebijaksanaan adalah berhati-hati dengan keputusan yang dibuat, tidak mengambil resiko, tidak mengatakan atau melakukan sesuatu yang tidak bertanggung jawab. Dalam kehidupan sehari-hari, seseorang akan meninjau secara hati-hati masa depan mereka, berpikir dan memiliki perhatian yang penuh terhadap masa depan membuat rencana yang matang dan menetapkan tujuan serta aspirasi jangka panjang. Konselor bertanya "apakah sudah mengerti?", konseli menjawab "iya teh". Konselor melanjutkan bertanya, apakah terdapat permasalahan konseli yang ingin disampaikan kepada konselor. Konseli berfikir sebentar dia pun menjawab, kalau dia sering tidak mengerjakan tugas karena malas, dia juga tidak suka menabung kalau punya uang suka tidak ada sisa hanya cukup saja.

Langkah II pemberian contoh modeling atau retensi, selanjutnya konselor sebuah film yang dipercepat, yang menceritakan anak muda yang berhasil sejak muda membantu melunasi hutang orang tuanya, bukan hanya dia berani tetapi juga memiliki kebijaksanaan. Mamapu berfikir jangka panjang, dan memikirkan baik buruk dalam setiap tindakan. Konselor mempersilahkan konseli untuk melihat film yang telah disediakan. Setelah selesai menonton konseli diminta menyebutkan makna dari film tersebut. Konseli berkata "si Tom orang yang ada di film itu sangat pemberani, dia mampu berhasil di usia yang muda, Tom bisa menyelesaikan semua permasalahan yang ada". Konselor membenarkan apa yang disampaikan konseli sambil menambahkan "betul sekali teh selain itu pelajaran yang bisa kita ambil dari film tadi, si Tom dalam menjalankan usahanya bukan hanya berani tetapi penuh pertimbangan, setiap dia mau memulai usaha pasti dia mau survei terlebih dahulu, Tom tidak malu untuk pergi kepasar, mengangkat barang-barang berat, jalan kaki jauh, yang membuat dia beda dengan remaja lainnya, selain itu Tom juga setiap mau mulai usaha selalu uji coba terlebih dahulu dan yang paling mulia walaupun jalan sebelumnya dia salah, akhirnya dia memutuskan berusaha sekuat tenaga agar bisa melunasi hutang orang tuanya yang sangat banyak". Lalu konselor menanyakan apakah konseli mengerti dan ada yang mau ditanyakan sebelum ke langkah selanjutnya, konselipun menjawab mengerti dan belum ada pertanyaan.

Langkah III latihan atau reproduksi motor, konselor mengarahkan agar konseli bisa bijaksana khususnya dalam salah satu masalah yang dia hadapi yaitu belum bijaksana dalam mengatur waktu, "baiklah teh sekarang kita praktik, coba teteh fikirkan jadwal teteh sehari-hari, bangun tidur jam berapa, terus ngapain setelah itu berangkat sekolah jam berapa, dan pulang sekolah pukul berapa, terus melakukan aktifitas apalagi sampai tidur lagi, agar teteh sempat mengarjakan semua tugas rumah dirumah, tanpa malas", konselor sambil berfikir, "saya bangun pagi jam 5, terus bantu-bantu tante sebentar, habis itu berangkat sekolah jam 06.15 atau 06.30, sampai sekolah jam 07.00, pulang sekolah jam 13.30, terus sampai rumah pukul 14.00, dirumah saya bantu nungguin warung tante sambil mengerjakan tugas, jam 16.00 mandi nonton TV sambil membantu apa saja pekerjaan tante sampai jam 19.00, habis itu belajar lagi, sambil negrjain tugas yang belum dikerjakan, pukul 21.00 tidur", konselor "bagus teh teruskan seperti itu dirumah juga yah supaya tidak ngerjain tugas di sekolah lagi, mungkin teteh bisa menambahnya belajar lagi pagi-pagi sebelum berangkat sekolah, dengan cara bangunnya lebih pagi" konseli menjawab "baik teh". Selanjutnya konselor menanyakan apakah ada yang konseli ingin tanyakan, dan konselipun menjawab tidak ada.

Langkah IV pekerjaan rumah atau umpan balik, baiklah teh sekarang teteh saya beri tugas di rumah untuk mempraktikan kebijaksanaan dalam kehidupan teteh sehari-hari, teteh juga bisa mencoba dengan lebih bisa mengatur keuangan agar bisa menabung sedikit-sedikit, seperti yang 
teteh sebutkan sebelumnya. Konselipun bersedia dengan hal tersebut. Ringkasan atau evaluasi, langkah ini dilaksanakan seminggu setelah pertemuan ini sebelum memulai konseling sesi selanjutnya. Konselor menanyakan bagaimana tugas rumahnya, konseli memaparkan "konseli mengaku lebih rajin mengerjakan tugas sekolah, lebih rajin mengerjakan pekerjaan rumah, mendamaikan teman yang berselisih, mendengarkan dan mengikuti nasihat orang tua", konselor memberi penghargaan dengan yang sudah dilakukan konseli dengan pujian, selanjutnya konselor menguatkan kembali kalau bijaksana itu penting, karena kita harus memikirkan apa yang kita lakukan akibat jangka panjangnya, kalau tidak suka mengerjakan tugas, boros dll, pasti ada hal negatif yang bisa kita alami dimasa depan.

Konseling sesi keempat dilaksanakan tanggal 26 Maret 2015 di ruang guru. Sesi dimulai dengan menanyakan kabar konseli "bagaimana kabarnya teh sehat?" konseli menjawab "sehat teh". Setelah itu, peneliti menanykan tugas rumah yang diberikan sebelumnya, konselipun menyerahkannnya dan yang hasilnya sudah dipaparkan di paragraf sebelumnya. Pada sesi ketiga konselor langsung ke langkah I yaitu rasional atau atensi menjelaskan sesi ketiga konseling dengan teknik modeling akan menggunakan media kisah nyata dan biografi orang-orang berhasil karena bisa mengontrol diri. Selanjutnya konselor bertanya "permasalahan apa yang dimiliki konseli?" konseli menjawab "saya gampang nangis kalau dinasihati tante karena merasa dimarahi, saya sering emosi kalau temen bikin kesel, saya juga suka gampang marah kalau mau datang bulan" konselor bertanya lagi, "apakah teteh punya pacar", konseli menjawab "dulu punya tapi sekarang sudah putus", terus konselor bertanya lagi apakah ada hal lain yang ingin konseli ceritakan, konseli menjawab "sepertinya tidak ada".

Selanjutnya langkah II pemberian contoh modeling atau retensi, konselor memperlihatkan 2 kisah nyata yang positif bisa mengontrol diri, dan 2 kisah nyata negatif yang tidak bisa mengontrol diri, kisah yang positif yaitu berita keberhasilan polwan, yang lolos seleksi menjadi polwan tanpa menyuap, polwan ini juga tidak malu untuk mencari penghasilan tambahan untuk orangtuanya menambal ban di rumahnya. Kisah positif keduanya yaitu ada remaja yang rela jadi penjaga sekolah demi cita-citanya untuk terus bersekolah dengan mengesampingkan rasa malu dan gengsi yang sering dirasakan para remaja. Kisah pertama negatifnya adalah artis korea yang bunuh diri karena depresi putus kontrak kerjanya, yang kedua kisah remaja yang berpacaran diluar batasan. Dari semua yang sudah dibaca konseli, konslor meminta makna apa yang bisa diambil dari kisah-kisah yang dibaca sebelumnya, konseli menjawab "em yang di baca tadi kita harus terus berusaha, tidak usah malu, harus jujur, harus bisa berfikir panjang sama tidak boleh pacaran diluar batasan". Konselor membenarkan itu dan melengkapi makna yang bisa diambil dari kisah yang sudah dibaca yaitu, dalam mencapai sesuaitu yang kita inginkan kita harus sabar sambil terus berusaha contohnya polwan tadi dia bisa jadi polwan walaupun bukan dari keluarga yang mampu, dia memegang teguh yang namanya nilia baik kejujuran, selanjutnya kita juga mengendalikan emosi dan ego kita demi kebaikan diri kita contohnya remaja yang menjadi penjaga sekolah demi terus melanjutkan sekolah, tanpa merasa malu atau gengsi. Selanjutnya walaupun sudah banyak contoh film yang menganggap pacaran itu biasa, sebaiknya kita orang yang mempunyai norma masyarakat dan agama tidak boleh berlebihan dan apapun masalah kita jangan sampai kita pendek berfikir untuk mengambil jalan pintas contohnya bunuh diri". Konselor menanyakan apakah konseli mengerti atau ada yang perlu ditanyakan, konseli menjawab sudah jelas.

Selanjutnya langkah III latihan atau reproduksi motor, konselor meminta konseli berlatih apa yang akan dia lakukan jika ada orang yang mengejek dia dan menyakiti hatinya, konseli menjawab "saya tidak akan langsung marah, tapi akan bilang kalau saya tidak suka", konselor berpura-pura jadi teman yang mengejek, "eh kamu orang jutek atau judes", apa yang akan kamu lakukan, konseli menjawab "saya bukan orang seperti itu jadi tolong jangan bilang seperti itu" konselor menjawab, bagus terus teteh berlatih seperti itu sampai teteh merasa nyaman.

Langkah IV pekerjaan rumah atau motivasi, selanjutnya konseli diminta menuslikan semua apa yang sudah lakukan dalam mengontrol diri selama seminggu. Evaluasi dan rangkuman setelah seminggu konseli ditanyakan apa lembar kerjanya, dan apa saja yang sudah dilakukan. Sebelum membahas konseling sesi selanjutnya. Konseli menceritakan "saya tidak suka marah-marah kepada teman, saya sudah sedikit mengerti kesalahan teman yang disengaja maupun tidak, saya sudah jarang bertindak semau sendiri, kalau teman mengejek saya tidak langsung marah”. Konselor meberikan penghargaan berupa pujian kepada konseli dengan apa yang sudah dilakukannya selain itu konselor juga memberi penguatan, kalau kontrol diri ini penting sekali dalam kehidupan seharihari, karena banyak jaman sekarang yang karena masalah kecil jadi besar karena tidak bisa mengendalikan diri. Konselor bertanya apakah konseli tau, apa yang dimaksud dengan bisa 
mengontrol diri, konseli menjawab "emm mengontrol diri itu, mengatur diri", konselor membenarkan sambil menambahkan "Kontrol diri yaitu mampu mengatur perasaan dan tingkah laku, disiplin, mengontrol emosi dan nafsu. Orang yang mampu mengontrol gairah, kebutuhan, dan dorongan serta menampilkannya pada kondisi yang memungkinkan. Saat berhadapan dengan situasi yang menyakitkan, orang mampu meregulasi emosinya, dan mengobati sendiri perasaan-perasaan negatif yang dirasakan", konselor menanykan apakah konseli mengerti, konselipun mejawab kalau sudah mengerti.

Sesi konseling diakhiri dengan kesimpulan kekuatan karakter kesederhanaan sangat penting karena didalamnya kita bisa menjadi orang yang pengampun dan belas kasihan, bijaksana, kontrol diri sehingga bermanfaat bagi keberhasilan hidup dimasa depan, baik dilingkungan masyarakat, keluarga, karir maupun pendidikan. Pengamatan guru JT dipandang masih tetap sebagai siswa yang pendiam tapi JT lebih terlihat lebih dekat dengan guru, tidak sungkan-sungkan ataupun tertutup. Pengamatan teman sekelasnya JT teman yang menyenangkan, menjadi lebih terbuka, baik mau membagi jajanan, JT mau memabantu mengerjakan tugas, dan lebih sabar tidak lagi sering kelihatan BT.

\section{Kasus Konseli DN}

Sesi konseling terhadap DN dilaksanakan sebanyak empat sesi. Sesi pertama dilaksanakan pada tanggal 5 Maret 2015, konseling dilakukan di ruang guru. Sebelum konseling dilaksanakan membangun hubngan akrab terlebih dahulu, mendiskusikan agenda konseling, menjelaskan manfaat dan tujuan konseling. Hal tersebut dilakukan dengan harapan konseli benar-benar mengikuti sesi konseling apa adanya tanpa rekayasa. Targetnya adalah siswa menyadari pentingnya keterlibatan siswa dalam mengikuti konseling. Tujuannya terjalin hubungan positif dengan konseli dan mengenalkan intervensi konseling dengan modeling simbolis dan kemampuan yang dapat diperoleh konseli.

Selanjutnya konselor memulai sesi konseling, konselor menanyakan kabar, "bagaimana kabarnya kang sehat?", konseli menjawab "sehat bu". Setelah itu konselor langsung ke langkah pertama yaitu rasional atau atensi, konselor menjelaskan konseling bertujuan untuk mengembangkan kekuatan karakter kesederhanaan. Hal ini bertujuan agar konseli dapat informasi yang jelas sehingga semangat dan aktif mengikuti sesi konseling. Pada sesi pertama konselor meminta konseli menceritakan masalah yang dimilki siswa, konselipun menceritakan kalau dia pernah dipukul oleh teman, karena dia menegur teman yang ramai dikelas, konseli merasa tertanggu sedang belajar matematika, selain itu konseli juga pernah dipukul oleh teman yang lain di kolam renang dan setelah diselidiki sepertinya karena konseli merasa diadu domba, dari kejadian itu semua konseli tidak melawan atau membalas, tapi konseli masih merasa sakit hati, masih teringat, dan sekarang hubungan dengan teman tersebutpun kurang begitu baik.

Selanjutnya langkah kedua yaitu pemberian contoh modeling atau retensi, konselor berkata "baiklah kang saya sudah mendengar masalah akang sebelum kita melanjutkan membahas masalah akang silahkan akang tonton vidieo ini terlebih dahulu". Video yang disajikan adalah tentang remaja yang tuna rungu selalu dibully temannya tapi dia tidak membalas, dia menjadi lebih semangat dan punya kekuatan agar tidak dibully dan diterima semua orang dengan berprestasi menjadi pemusik. Setelah konseli menonton konselor menanykan makna yang bisa diambil dari video itu konseli menceritakan "walau kita disiksa orang lain, kita harus semangat untuk maju", konselor memberi penghargaan dengan jawaban konseli sambil menambahkan kalau "betul kang yang dari video tersebut kita bisa mengambil makna, kalau kita disakiti orang lain, kita tidak usah melupakan sepenuhnya masalah sebelumnya, tapi kita juga harus bersedia mengampuni dan memberi kesempatan kedua, dengan cara kita lebih baik pada orang tersebut, dan kitapun seharusnya menjadi orang yang lebih baik" konseli menjawab "oh iya bu", terus konselor melanjutkan "dengan masalah yang akang tadi ceritakan mungkin akang tidak bisa melupakan kekasaran teman kang tidak apaapa, akang sudah tepat dengan tidak membalasnya, sekarang akang tinggal belajar untuk menjadi bersikap lebih baik kepada dia, akang juga bisa instropeksi diri supaya akang bisa menjadi orang yang menjadi lebih baik" konseli menjawab "iya bu, tapi sulit".

Selanjutnya langkah latihan atau reproduksi motor. Konselor melanjutkan "tentu sulit, makanya sekarang mari kita latihan, pura-puranya saya teman akang lewat didepan akang, apa yang mau akan katakan", konseli berfikir sebentar terus berkata "saya mungkin mau nyapa bu, mau pergi kemana?" konselor memberi penghargaan dan sambil memberi saran "mungkin akang juga bisa ajak teman akang untuk duduk bersama supaya bisa mengobrol", konseli menjawab "saya menyapa dulu saja bu", konselor "baiklah silahkan latihan dulu sambil membayangkan, sampai akang merasa nyaman". 
Langkah pekerjaan rumah atau motivasi, "baiklah sekarang saya beri akang pekerjaan rumah, tulis semua kgiatan akang yang menunjukan akang mempraktikan mengampuni kesalahan orangorang disekitar kang yang akang anggap berbuat salah kepada akang, seminggu lagi, bawa hasil lembar kerjanya?", jawaban konseli “ oh iya bu”. Evaluasi dan ringkasan, sebelum memulai sesi konseling selanjutnya setelah seminggu konselor menayakan hasil lembar kerja "bagaimana lembar kerjanya, dikerjakan kang?" konseli menjawab, "iya bu”, konselor bertanya "apa saja yang akang sudah lakukan?" konsli menjawab "saya membantu orang menyebrang jalan, memaafkan teman terlebih dahulu, meminta maaf kepada teman, saya tidak melawan ketika dimarahi atau disuruh orang tua, saya berbagi makanan dengan teman, saya membantu beres-beres rumah, itu mungkin bu", konselor memberi penghargaan "oke bagus kang teruskan yah, berusahalah menjadi lebih baik dari hari kehari, baik kepada orang yang menyakiti akang maupun yang tidak" konseli menjawab "baik bu". Selanjutnya meneruskan sesi konseling.

Sesi konseling kedua dilasanakan tanggal 13 Maret 2015 di ruang guru SMK Vijaya Kususma, sesi dimulai dengan menanyakan kabar "bagaimana kabarnya kang, sehat?" konseli menjawab "Alhamdulillah sehat bu", selanjutnya konselor menanyakan lembar kerja yang dikerjakan minggu sebelumnya yang sudah dijelaskan diparagraf sebelumnya. Langkah I rasional atau atensi, konselor menjelaskan sesi konseling dengan teknik modeling simbolis ini akan menggunakan media biografi orang yang berhasil karena rendah hati, sebelumnya konselor menayakan apakah konseli bisa cerita masalah yang masih terjadi sehari-hari dan membuat konseli cukup terganggu, konseli bercerita "saya sedikit terganggu dengan teman yang tidak bisa dibilangin", konselor bertanya "maksudnya bagaimana kang", konseli menjawab "sayakan sering ngasih tahu soal pelajaran, eh masih ada temen yang kalau dikasih tahu itu semaunya sendiri, ya sudah suka saya biarin dan tinggalkan, biarin saja dia salah juga”, konselor “oh begitu, ada lagi yang ingin akang ceritakan?", konseli menjawab "itu dulu mungkin bu".

Langkah kedua pemberian contoh modeling atau retensi, konselor memberi pengantar "sebelum kita bahas masalah kang DN tadi mari kita baca biografi ini", konseli "baik bu", biografi yang diperlihatkan adalah biografi Ir. H. Joko Widodo, Prof. Dr. H. Bacharuddin Habibie dan pemain bola Chambers. Setelah konseli selesai membaca, konselor menanyakan apa makna yang bisa diambil dari biografi orang-orang tersebut, konseli menjawab "beliau berhasil dengan cara yang tidak mudah ya bu, dari bawah terlebih dahulu", konselor "betul sekali, beliau-beliau bisa berhasil dengan proses perjuangan yang keras, dan dengan budi pekerti yang baik, yang sisi baiknya bisa kita contoh, contohnya presiden kita Jokowi dodo beliau banyak yang menyangka tidak akan jadi presiden karena orangnya sangat sederhana, tapi karena rendah hati dan bisa membumi dengan rakyat biasa, ternyata beliau bisa juga jadi presiden, dan beliau memiliki pabrik meubelpun tidak mudah dia beruasaha dari bawah, begitu juga dengan pak habibie dan pemain bola ini", konseli "oh iya", konselor "nah jadi apa yang sebaiknya akang lakukan kepada teman yang menurut akang menyebalkan tadi itu?", konseli "seharusnya saya terus mengajarkan dia sampai bisa, mungkin dia menyebalkan karena saya belum bisa mengejarkan dengan jelas" konselor "bagus".

Langkah III latihan atau reproduksi motor, konselor "supaya kata-kata akang bisa dimengerti teman akang bagaimana caranya?", konseli "saya harus bicara pelan-pelan dan kata-kata yang baik mungkin ya bu?" konselor "bagus, contohnya seperti apa?", konseli "setauku bukan gitu tapi gini”" konselor "bagus silahkan lanjutkan latihan sampai terdengar tidak menyalahkan, sampai akang merasa nyaman".

Langkah IV pekerjaan rumah atau motivasi, setelah langkah III selesai konseli meminta konselor membawa lembar kerja rumah, untuk dituliskan semua kegiatan yang menunjukan konseli rendah hati, dan harus diserahkan pertemuan selanjutnya. Evaluasi dan ringkasan sebelum dilanjutkan ke sesi konseling selanjutnya konselor menanyakan lembar kerja yang diberikan untuk dilaporkan, konseli menyebutkan " saya tidak pilih-pilih teman dalam bergaul, saya tidak merasa paling bisa, saya memperhatikan guru pada saat pelajaran, saya berusaha solat tepat waktu, aktif pramuka, saya juga akrab dengan semua teman", konselor memberi penghargaan, "bagus kang, kita bisa mengambil hikmah dari orang-orang sekitar, orang yang rendah hati banyak yang menyayangi dan membantu, mungkin yang sekarang orang yang akang anggap tidak bisa suatu saat bisa membantu akang dalam kesulitan walaupun kitak boleh mengharapkannya, kalupun tidak, Tuhan juga pasti mebantu kita dalam disetiap kesulitan", konseli "iya bu". Melaksanakan konseling selanjutnya.

Konseling sesi keempat dilaksanakan tanggal 20 Maret 2015 di ruang guru SMK Vijaya Kusuma Bandung, sesi dimulai dengan menanyakan kabar "bagaimana kabarnya kang DN?", konseli menjawab "Alhamdulillah baik bu", sebelum melanjutkan konseling ke sesi selanjutnya 
konselor meminta lembar kerja konseli yang sudah dijelaskan diparagraf sebelumnya. Selanjutnya melanjutkan konseling sesi keempat, langkah pertama rasional atau atensi konselor menjelaskan konseling dalam sesi ini akan menggunakan media film, tapi sebelum melanjutkan sesi konseling konselor meminta konseli menceritakan masalah diri konseli yang merasa membuatnya terganggu, konseli bercerita "begini bu saya itu kadang kalau lagi asik dengan kegiatan saya sendiri, kalau dibilangin orang tua kadang-kadang melawan", konselor, “contohnya apa kang?", konseli menjawab, "ya biasa bu kalau dinasihati orang tua gitu", konselor "oh begitu, terus akang tidak suka berfikir dulu kalau akang melawan, mungkin menyakiti hati orang tua dan pasti yang dinasihati orang tua baik buat akang", konseli menjawab, "iya bu kalau lagi kondisi seperti itu saya jarang berfikir sampai kesana", konselor "baiklah kang saya mengerti maksud akang, sebelum kita melanjutkan sesi konseling, sekarang akang silahkan lihat film ini.

Langkah kedua pemberian contoh modeling atau retensi, film yang ditayangkan menceritakan remaja yang berhasil menjadi penguasaha tingkat internasional, bukan hanya bermodal keberanian tapi juga kebijaksanaan, setiap memulai usaha remaja tersebut selalu survei dan uji coba terlebih dahulu dan remaja tersebut juga mempunyai tujuan untuk membantu melunasi hutang orang tuanya. Setelah konseli melihat totonan konselor bertanya apa makna yang bisa diambil dari film tersebut, konseli menjawab "orang yang ada didalam film berhasil menjadi pengusaha karena terus berusaha tanpa putus asa", konselor membenarkan dan menambahkan "betul kang ditambah juga, orang tersebut sangat bijaksana, dia tahu apa yang mau dia lakukan, walaupun sempat gagal semuanya penuh perhitungan, dan tidak hanya bermodal nekad", konseli "oh iya bu", konselor "nah saya juga berharap akang bisa merubah sikap akang kepada orang tua, walaupun akang belum bisa membantu orang tua akang seperti yang difilm tadi paling tidak akang bisa menghargai orang tua akang terlebih dahulu, kalau mau bicara kepada orang tua difikirkan terlebih dahulu" konseli "oh iya bu", konselor "apa yang akang akan ubah sekarang kalau sudah mengetahui manfaat jadi orang bijaksana", konseli "saya mau mencoba lebih baik bersikap maupun berkata-kata kepada orang tua bu", konselor "bagus kang".

Langkah ketiga latihan dan praktek. Konselor "baiklah kang sekarang kita latihan, purapuranya saya orang tua akang yang mensihati akang, DN kamu itu kalau sekolah yang bener, jangan main terus", konselor bertanya apa yang akan DN lakukan, konseli menjawab "iya bu, saya main karena ada pekerjaan kelompok yang harus saya kerjakan", konselor "ok kang terus latihan sampai apa yang akang katakan tidak terdengar membentak, dan bayangkan bagaimana keadaan dirumah saat itu", konseli "baik bu".

Langkah pekerjaan rumah atau motivasi, konseli diminta untuk mengisi lembar tugas rumah yang menuliskan kegiatan konseli sehari-hari dan tuliskan juga perubahan apa yang konseli lakukan untuk menjadi lebih bijaksana, selanjutnya konseli diminta melaporkan lembar tugasnya tersebut minggu selanjutnya. Evaluasi atau umpan balik, konselor menanykan apa saja yang sudah dilakukan konseli untuk mencoba lebih bijaksana, konseli memaparkan "saya suka menyisihkan sisa uang jajan, buat keperluan yang ada, saya jajan tidak berlebihan, saya mencoba untuk menabung, ketika diberi tugas menulis atau merangkum ada perasaan malas, tapi saya berfikir pasti selesai, saya beres-beres rumah ketika ibu saya sakit". Konselor memberi penghargaan dan memberikan penguatan agar konseli terus beruasah menjadi orang yang lebih bijaksana, segala sesuatu difikirkan terlebih dahulu baik bauruknya, supaya tidak menimbilkan penyesalan dikemudian hari.

Konseling sesi ketiga dilaksanakan tanggal 26 Maret 2015 di ruang guru SMK Vijaya Kusuma, sesi dengan menanyakan kabar koseli "bagaimana kabarnya kang DN seminggu ini” konsli menjawab "Alhamdulillah baik bu", selanjutnya konselor menanyakan lembar kerja sebelumnya yang ditugaskan, seperti yang diterangkan di paragraf sebelumnya. Setelah selesai sesi konseling ketiga dilaksanakan langkah I rasional atau atensi, konselor menjelaskan konseling dengan teknik kodeling simbolis pertemuan ketiga ini akan menggunakan media tokoh-tokoh orang dari contoh positif maupun negatif, konselor menanyakan kesiapan konseli, konselipun menjawab "siap bu", konselor "baiklah kang sebelumnya tolong ceritakan mungkin masih ada masalah seharihari yang mau akang ceritakan?", konseli berfikir sebentar terus menyebutkan "paling saya kadang kebawa emosi kalau dijailin temen saat belajar, ketiduran waktu belajar, pernah juga sambil bercanda di motor sama teman sampai mau jatuh", konselor "oh iya, ada lagi mungkin yang mau diceritakan?", konseli menjawab, "itu dulu mungkin bu".

Langkah kedua pemberian contoh modeling atau retensi, konselor "baiklah kang selanjutnya silahkan akang baca kisah-kisah orang yang sudah saya siapkan", konseli "baik bu", kisah-kisah yang disajikan terdiri dari dua kisah positif dua kisah negatif, yaitu kisah polwan yang berhasil lolos seleksi tanpa menyuap dan mencari biaya tambahan hidup dengan menambal ban, siswa yang 
bersedia jadi penjaga sekolah demi melanjutkan sekolah dan yang negatifnya berita remaja yang pacaran diluar batas, serta artis korea yang bunuh diri. Setelah konseli membaca konselor meminta konseli menjelakan makna yang bisa diambil dari cerita yang dibaca, konseli "terdapat orang yang bisa berhasil walaupun dari kelaurga yang sederhana, ada juga yang bunuh diri karena prustasi, ada juga yang prustasi terus bunuh diri", konselor "konselor mebenarkan itu, dan menjelaskan lebih dalam, yang akang baca adalah kisah polwan yang berhasil lolos seleksi jadi polwan dengan jujur, tidak seperti orang lain yang menyuap, terus remaja seumuran akang mau bekerja sebagai penjaga sekolah supaya bisa terus sekolah karena tidak mempunyai biaya, jaman sekarang jarang anak muda yang seperti itu, pasti malu atau gengsi, nah yang negatifnya, ada artis cantik bunuh diri karena prustasi karena kontrak kerjanya berakhir, sama anak remaja yang pacaran diluar batas", selanjutnya konselor bertanya apa hikmah yang bisa diambil dari kisah tersebut, konseli menjawab "kita harus terus berusaha jangan putus asa bu", konselor "benar, selain itu kita juga harus bisa mengendalikan diri, dari perasaan maupun sikap negatif, jadi apa yang bisa akang terapkan dengan permasalahan yang akan ceritakan sebelumnya?" konseli "oh iya, saya harus bisa mengendalikan diri dalam bermain supaya tidak menjelaskan diri saya sendiri, saya juga harus mengendalikan diri supaya tidak gampang emosi kepada teman yang menjaili saya dan harus bisa mengendalikan diri supaya tidak tidur dikelas", konselor memberi penghargaan dengan pujian.

Langkah latihan atau reproduksi motor "baiklah kang DN sekarang kita latihan apa yang akan akang lakukan jika teman akang bercanda menjaili akang saat akang lagi sibuk belajar?", konseli menjawab "saya mau bilang, "diam dulu, nanti kita bermain lagi", konselor "bagus, tapi mungkin lebih baik supaya awalnya ada kalimat tolong", konseli "oh iya, tolong diam dulu, nanti kita main lagi, bagus sekarang akang latihan sampai kedengeran sudah nyaman dan tidak membentak, konseli "baik bu". Setelah dikira cukup, konselor menyarankan konseli juga berlatih untuk mengontrol diri yang lainnya di sesi konseling.

Langkah pekerjaan rumah atau motivasi, konseli dibeli lembar tugas untuk menulis semua kegiatan yang dia lakukan untuk latihan mengendalikan diri, dan meminta konseli mengumpulkan minggu selanjutnya, dipertemuan yang akan datang. Evaluasi dan ringkasan, sebelum memulai konseling sesi keempat koselor menanyakan tugas rumah yang sudah diberikan seminggu sebelumnya, konseli menceritakan "saya tidak cepat marah kepada teman yang bercanda di kelas, saya mencoba mengikuti semua tata tertib sekolah, saya tidak mengikuti teman yang mengajak ke hal yang negatif', konselor memberi penghargaan kepada konseli berupa pujian dan meminta konseli untuk terus berlatih dan mengaplikasikan diri agar terus bisa mengendalikan diri.

Kesimpulan dari keseluruhan kekuatan karakter kesederhanaan konseli merasa banyak manfaat yang bisa diambil dari setiap sesi konseling, diantaranya dia mengaku lebih sering membantu teman, lebih patuh pada orangtua, mengatur waktu buat belajar, membantu orangtua dan ibadah, konseli juga mengaku lebih tepat waktu mengerjakan tugas. Menurut gurunya DN mau lebih membantu teman yang sedang kesulitan dalam pelajaran praktik, perilaku ke guru dianggap baik dan dekat. Menurut temannya DN lebih sabar kalau diejek temannya atau terdapat teman yang membuatnya kesal, DN mau meminta maaf terlebih dahulu ketika ada masalah dengan temannya.

\section{Kasus Konseli SH}

Konseling terhadap SH dilakukan sebanyak 4 sesi, sesi yang dilakukan sebagai berikut, sesi pertama dilaksanakan tanggal 5 Maret 2015 di ruang guru SMK Vijaya Kusuma Bandung. Sesi dimulai dengan menanyakan kabar konseli, "bagaimana kang kabarnya, baik?”, konseli menjawab "Alhamdulillah". Selanjutnya masuk ke lanngkah pertama yaitu rasional atau atensi, konselor menjelaskan konseling yang akan dilakukan adalah dengan teknik modeling simbolis, dijelaskan setiap pertemuan akan ada media sebagai pembantu melihat contoh. Selanjutnya konselor menanyakan apakah konseli mempunyai masalah yang bisa dibagi bersama konselor untuk dicari jalan keluarnya. Selanjutnya konseli menjawab, "em apa ya, saya suka diejek sama teman di kelas, habis itu jadi diem-dimean tidak saling bicara", konselor bertanya "contohnya diejek bagaimana?", konseli menjawab "adalah bu, biasa suka ledek-ledekan", konselor bertanya lagi, apa yang dirasakan konseli saat diejek, konseli menjawab "saya sakit hati bu, malu sama teman yang lain kesal lagi”, konselor berempati memberikan isyarat kalau mengerti. 
Langkah kedua pemberian contoh modeling atau retensi, konselor mengarahkan "baiklah kang sebelum kita melanjutkan membahas akang tersebut silahkan akang lihat tayangan video yang akan saya putarkan, konseli menjawab "baik bu". Video yang diputarkan adalah tentang siswa tuna rungu yang dibully oleh temannya, tetapi dia tidak balas dendam, dia berusaha lebih baik agar bisa diterima oleh temannya. Setelah konseli selesai menonton video, konselor menanyakan makna video tersebut konseli menjawab "ada anak sekolah yang selalu di siksa oleh temannya, dia tidak membalas, tapi dia malah berhasil jadi pemain biola". Konselor membrikan penghargaan pujian terhadap jawaban konseli selanjutnya konselor memperdalam makna yang bisa dimabil dari video, "betul yang disampaikan akang, saya tambahkan, remaja yang ada dalam video seorang tuna rungu, yang selalu dibully oleh temannya karena tidak mendengar, tapi dia punya cita-cita untuk jadi pemusik, dia tidak konsentrasi kepada kesalahan temannya, tapi dia juga konsentrasi pada mimpinya, walaupun menurut orang lain tidak bisa dia membuktikan bisa, tentunya dengan dukungan orang-orang disekitar, dia tidak membalas dendam kesalahan temannya". Konseli menjawab "oh iya bu", nah sekarang saya harap akang bisa bersikap baik kepada orang yang memusuhi akang, mungkin akang tidak perlu melupakan kesalahannya tapi bisa bersikap lebih baik, agar dia juga tidak melakukan hal yang sama kepada akang, konseli menjawab "baik bu".

Langkah ketiga latihan atau reproduksi motor, konselor "baiklah kang kita latihan, purapuranya saya teman akang, saya mengejek akang, coba akang beri jawaban dan bayangkan akang akan bersikap seperti apa, oke?", konseli menjawab "baik bu", konselor "heh SH kamu tuh kurus", "apa yang akan kamu perbuat kang", konseli menjawab, "saya tidak akan langsung tersinggung bu, saya akan bilang benar aku kurus, tapi tolong jangan bilang seperti itu terus", konseli "bagus kang teruskan berlatih seperti itu sampai akang merasa nyaman dan menerima, sampai kata-kata kang juga kedengeran tidak terlalu kaku, konseli menjawab "baik bu", setelah selesai dilanjutkan kelangkah empat.

Langkah keempat pekerjaan rumah atau motivasi, konselor "baiklah kang sebelum akang kekelas, saya minta akang mengerjakan lembar tugas rumah selama seminggu tulis kegiatan akang yang mencerminkan akang mengampuni kesalahan orang, konseli menjawab "baik bu". Rangkuman atau evalusi, seminggu selanjutnya sebelum melakukan konseling selanjutnya konselor mengevalusi pekerjaan rumah konseli. Konselor "bagaimana kang lembar tugasnya sudah dikerjakan?", konseli menjawab "sudah bu, sudah diisi", konselor memberi penghargaan dan menanyakan apa saja yang sudah dilakukan, konseli menjelaskan " saya membantu orang yang menyebrang jalan, saya memaafkan kepada teman yang membuat saya kesal, saya tidak melawan ketika disuruh orang tua, saya membagi makanan kepada teman, saya bantu-bantu orang tua beres-beres rumah". Konselor memberikan penghargaan kepada konseli dan menyarankan konseli terus melakukan apa yang sudah dilakukannya.

Konseling sesi kedua dilaksankan 13 Maret 2015 di ruang guru SMK Vijaya Kusuma, awal pertemuan konselor menanyakan kabar konseli, "bagaimana kang kabarnya sehat?", konseli menjawab "baik bu". Selanjutnya konselor menanyakan apakah tugas rumahnya sudah dikerjakan atau belum, yang sudah dipaparkan diparagraf sebelumnya. Selanjutnya kelangkah pertama konseling sesi kedua yaitu rasional atau atensi, konselor menjelaskan sesi konseling kedua akan menggunakan media biografi orang yang berhasil. Sebelumnya konselor bertanya apakah ada yang mau diceritakan masalah konseli, konseli berfikir sebentar terus menceritakan "kalau dia memiliki masalah, sulit meminta maaf kepada orang lain dan kadang milih-milih teman", konselor bertanya apa yang dia rasakan dan pikiran kenapa seperti itu, konseli menjawab "karena gengsi, ada rasa malu, terus kalau pilih-pilih teman karena kalau teman yang kira-kira menyebalkan sudah malas ngobrol juga, konselor bertanya apakah konseli mau berubah, konseli menjawab "mau tapi kadang tidak peduli juga", konselor memberikan isyarat kalau mengerti apa yang dimaksud konseli.

Langkah kedua pemberian contoh modeling atau retensi, konselor meminta konseli membaca biografi orang yang berhasil karena pribadinya yang rendah hati, yaitu Ir. H. Joko Widodo, Prof. Dr. H. Bacharuddin Habibie dan pemain bola Chambers setelah konseli selesai membaca konselor menanyakan apa makna yang bisa diambil dari hasil bacaan konseli, konseli menjawab, "orangorang yang berhasil, karena perjuangan dari bawah", konselor menjawab dan menjelaskan "betul kang, beliau-beliau berhasil salah satu yang berperan adalah karena memiliki kepribadian yang rendah hati, selain punya keahlian, banyak yang menolong juga karena tertarik dengan kepribadiannya yang rendah hati. Konseli menanggapi "oh iya bu", konselor menjelaskan "saya harap akangpun demikian kalau merasa akang salah segera minta maaf, dan jika ada teman terima kalau memang mau berteman dengan akang", konseli menjawab "baik bu". 
Langkah ketiga latihan atau reproduksi motor, konselor "baiklah kang sekarang kita latihan puran-puranya saya orang yang akang sakiti, apa yang akang lakukan?" konseli mejawab "saya akan minta maaf", konselor bertanya "bagaimana minta maafnya?", konseli "maafin aku ya", konselor meminta konseli terus berlatih sampai tidak terdengar canggung dan tulus, dengan konseli membayangkan situasi sesungguhnya. Setelah selesai dilanjutkan kelangkah keempat.

Langkah keempat pekerjaan rumah atau motivasi, konseli diminta mengerjakan tugas rumah dengan menjelaskan apa yang sudah dilakukannya, selama seminggu yang mencerminkan konseli berusaha untuk rendah hati. Kesimpulan atau evaluasi setelah seminggu sebelum memulai konseling sesi selanjutnya konseli ditanya hasil tugas rumahnya, konseli menceritakan "meminta maaf terlebih dahulu kepada teman, tidak memilih-milih teman dalam bergaul, berterimakasih apa yang sudah diberikan orang tua, tidak sombong kepada teman yang memusuhi, memperhatikan guru saat pelajaran". Konselor memberikan penghargaan pujian dan meminta konseli terus berlatih dan mempraktikan dalam kehidupan sehari-hari agar menjadi pribadi yang rendah hati.

Konseling sesi ketiga dilaksanakan 20 Maret 2015 di ruang guru SMK Vijaya Kusuma. Awal pertemuan konselor menanyakan kabar konseli, "bagaimana kang kabarnya?", konseli, "sehat bu". Sebelum memulai konseli sesi ketiga konselor menanyakan tugas rumah konseli yang sudah dijelaskna dalam paragraf sebelumnya. Selanjutnya konselor memulai konseling sesi ketiga dengan langkah pertama yaitu rasional atau atensi, konselor menjelaskan sesi ketiga akan dilaksanakan konseling dengan media film, yang sebelumnya menanyakan masalah konseli yang mau diceritakan konseli "saya sekarang lagi belajar untuk tidak merokok lagi bu, tapi masih ingin kalau diajak main sama teman takut kebawa-bawa lagi”, konselor memberikan penghargaan dengan memuji niatnya, selanjutnya konselor menanyakan apa manfaat merokok, konseli menjawab, "tidak ada, cuma seru saja sama teman-teman", terus konselor bertanya apa akibat negatifnya, konseli menjawab "bisa ngabisin uang, kurus, dll yang tertera dalam bungkusnya bu", konseor "nah itu bagus akang sudah berfikir akibat baik buruknya dan tidak ada keuntungannya merokok, akang juga sedang berusaha untuk menghentikannya". Konseli "tapi saya kadang ingin ikut sama teman-teman bu", konselor "akang berteman dan berbuat baik itu harus sama semua orang tapi kalau mau bersahabat lebih baik dengan yang membawa dampak baik kepada kita, selain mereka memang tidak ada teman lain yang tidak merokok?", konseli "ada bu". Konselor "terus sekarang bagaimana apa yang akang lakukan jika ada teman yang suka merokok ngajak jalan?”, konseli “saya mau menolaknya bu”.

Langkah kedua pemberian contoh modeling atau retensi, konseli diminta nonton film, yang menceritakan remaja yang berhasil jadi pengusaha bertahap internasional, yang selalu dipikirkan apa yang akan dilakukannya, tidak gengsi maupun terpengaruh remaja lainnya. Setelah selesai konseli menanykan makna yang bisa diambil dari film tersebut, konseli "dalam hidup tidak boleh menyerah, terus berjuang, tidak terpengaruh orang lain", konselor memberikan pujian sambil menambahkan, kalau yang diceritakan divideo, remaja tersebut tidak seperti remaja yang kebanyakan sehingga diusia muda dia bisa berhasil, salah satu yang sangat berperan dalam keberhasilannya karena dia selalu berfikir segala sesuatu yang akan dilakukannya baik maupun buruknya, begitu juga dengan masalah konseli diharapkan tidak terpengaruh orang lain kalau masaslah negatif dan difikirkan matang-matang sebelum berbuat sesuatu.

Langkah ketiga latihan atau reproduksi motor konselor bertanya apa yang akan dia lakukan kalau ada teman ada yang nagajak main malam atau merokok, konseli menjawab "saya akan menolaknya, karena itu berdampak buruk buat saya", konselor "bagaimana contohnya kalau saya teman akang, hai SH ayo keluar bosan ngeroko yu?", konseli menjawab "ah tidak aku lagi ada kerjaan dirumah disuruh orang tua", konselor meberikan pujian sambil meminta konseli terus beraltih sampai dia merasa yakin.

Pekerjaan rumah atau motivasi, setelah langkah ketiga, konseli diminta untuk mengerjakan tugas rumah selama seminggu menuliskan apa saja yang konseli lakukan yang mencerminkan dia berusaha untuk bijaksana. Ringkasan atau evalusai sebelum memulai sesi konseling keempat konselor meminta konseli menceritakan apa yang sudah dilakukan selama seminggu, konseli "saya selalu berfikir dulu sebelum bertindak, tidak hanya memikirkan kesenangan, saya juga berusaha bersikap adil bijaksana jika ada teman yang berselisih, saya sekarang tidak suka bercanda yang berlebihan, saya juga bisa menolak teman yang mengajak ke hal yang negatif'. Konselor memberikan penghargaan dan meminta konseli terus berlatih dan mengaplikasikan kalau dalam bertindak difikirkan dampak negatif maupun baiknya terlebih dahulu.

Konseling sesi keempat dilaksanakan 26 Maret 2015 di ruang guru SMK Vijaya Kusuma, sesi keempat dimulai dengan menanyakan kabar konseli konseli menjawab "baik bu", konseli bertanya dengan hasil lembar kerja selama seminggu yang sudah seperti dijelaskan sebelumnya. Langkah 
pertama rasional atau atensi, konselor menjelaskan konseling sesi keempat akan menggunakan media pakai kisah orang yang berhasil karena memiliki peribadi yang positif dan ada kisah negatifnya juga, tapi sebelum melanjutkan konselor menanyakan permasalah konseli, konseli menjawab "saya kadang berantem sama kakak dirumah karena masalah sepele, mungkin dia suka terlalu jail, atau rebutan remot TV macam-macamlah tapi itu cukup mengganggu saya", konselor bertanya, apakah kakanya umurnya tidak berbeda jauh, konseli menjawab "jauh bu dia sudah kerja". Konselor "oh iya saya mengerti, ada yang mau diceritakan lagi?", konseli "masalah saya yang lain mungkin tidak bisa menghemat uang jajan, suka habis-habis terus", konselor bertanya kenapa selalu habis kalau punya keinginan berhemat, konseli menjawab "karena ingin jajan seperti orang lain atau capek disekolah ingin minum" konselor mengerti apa yang dimaksud konseli, selanjutnya kelangkah kedua.

Langkah kedua pemberian contoh modeling/ retensi, konselor meminta konseli membaca kisah orang yang berhasil jadi polwan tanpa menyuap dan tidak malu untuk menjadi tukang tambal ban untuk tambah penghasilan, serta anak yang tidak malu jadi penjaga sekolah demi menyelesaikan sekolahnya. Contoh negatifnya kisah artis koea bunuh diri karena depresi dan remaja yang pacaran diluar batas, setelah konseli membaca kisah-kisah orang tersebut konselor bertanya apa makna yang konseli bisa dimabil dari hasil bacaannya, konseli menjawab, "ternyata bisa berhasil juga walaupun awalnya kesusahan dan berakibat tidak baik kalau berlebihan pacaran atau meimikirkan suatu masalah", konselor membenarkan hal tersebut, dan menambhakan orang yang berhasil itu bisa mengendalikan diri, dari rasa malu, maupun godaan untuk melakukan curang, dan yang negatif itu contoh yang tidak bisa mengendalikan diri sehingga berakibat negatif. Selanjutnya konselor bertanya apa yang akan dilakukan konseli dengan sikapnya yang boros maupun gampang emosi kepada kakaknya, konseli menjawab akan lebih behemat dan akan lebih menghargai kakaknya.

Sesi ketiga latihan atau reproduksi motor, konselor "baiklah kang mari kita latihan apa yang sudah akang rencanakan, contohnya akang diberikan uang 5000 buat jajan akang harus menabung 2000 sehari kalau akang lapar dan haus akang akan beli apa disekolah?" konseli menjawab "saya akan beli minum yang seribuan, dan gorengan 3 dua ribu", konselor "kalau kakak akang jailin akang dirumah apa yang akang lakukan, akan saya ikutin tapi kalau sudah menyebalkan saya akan bilang sudahan", konselor "oke sekarang akang latihan bicara yang baik dan sopan kepada kakak akang seperti apa menolaknya?", konseli "udah A aku pengen nonton TV dulu, nanti lagi", konselor "bagus terus akang latihan dan bayangkan apa yang akan lakukan sampai terkesan tidak membentak, dan tidak emosi sehingga tidak bertengkar, konseli "baik bu".

Pekerjaan rumah atau motivasi, konselor meminta konseli mengerjakan pekerjaan rumah dan menuliskan apa yang sudah yang sudah dilakukan yang mencerminkan dia sudah bisa mengendalikan diri. Kesimpulan, setelah seminggu konseli diminta hasil pekerjaan rumahnya, konseli menjelaskan, konseli jadi tidak mudah marah, mengikuti sekolah aturan yang berlaku, konseli menjawab dia menjadi tidak lebih emosi jika menghadapi masalah. Kesimpulan dari kekuatan karakter kesederhaaan konseli mengaku lebih dapat bisa mengontrol diri ketika ada teman jail, konseli juga lebih memikirkan dampak baik buruknya ketika akan melakukan sesuatu dan dapat mengerjakan tugas tepat waktu. Menurut gurunya SH pendiam, tapi baik. Menurut temannya SH mudah memaafkan temannya, suka memabntu teman yang kesulitan mengerjakan soal-soal dari guru, SH suka bercanda main dengan temannya tapi kadang juga terlihat minder kalau lagi becanda.

\section{PEMBAHASAN}

Penelitian konseling individu dengan teknik modeling simbolis terbukti efektif dapat mengembangkan kekuatan kesederhanaan (Usman et al., 2017). Tiga konseli yang menjadi subjek penelitian ditemukan bahwa setelah diberikan intervensi konseling individu dengan teknik modeling simbolis.

Modeling simbolis, model disajikan melalui bahan-bahan tertulis, audio, video, film atau slide (Lestari, 2015). Modeling simbolis dapat disusun untuk klien individu atau dapat distandarisasikan untuk kelompok klien (Nursalim, 2005). Film dan televisi menyajikan contoh tingkah laku yang tidak terhitung yang mungkin mempengaruhi pengamatannya (Alwisol, 2007).

Lickona (Mulyasa, 2011) meneyebutkan "desiring the good" atau keinginan untuk melakukan kebajikan. Dalam hal ini ditegaskan bahwa pendidikan karakter yang baik bukan hanya melibatkan aspek "knowing the good", tetapi juga "desiring the good" atau loving the good" dan "acting the good", sehingga manusia tidak berperilaku seperti robot diindoktrinasi oleh paham tertentu. Senada dengan pendapat Lickona, konseli JT, DN dan SH bukan tidak memilki karakter baik, tetapi itu semua belum menjadi kebiasaan atau 
kekuatan karena konseli belum menyadari atau merasakan manfaat dari kekuatan karakter yang tercermin dalam pikiran, perasaan, maupun perbuatan.

Pelaksanaan konseling kepada konseli JT berjalan dengan baik karena konseli JT terlibat aktif dalam mengikuti sesi konseling sehingga JT mudah memahami tujuan dan manfaat sesi konseling. Konseli DN terlibat aktif dalam sesi konseling dari awal sampai kahir. Demikian juga dengan konseli SH mengikuti sesi konseling awal sampai akhir, walaupun dalan sesi konseling konseli SH banyak diam hanya bicara yang diperlukan sesuai dengan pribadinya yang pendiam.

Gunarsa (Ali et al., 2009) perubahan sikap cukup menyolok dan ditempatkan sebagai salah satu karakter remaja adalah sikap menentang nilai-nilai dasar hidup orang tua dan orang dewasa lainnya. Konseli JT, DN dan SH sesuai dengan pendapat Gunarsa tersebut. Seperti konseli JT yang mempunyai hubungan kurang baik dengan bibinya, karena dia merasa suka dimarahi terus, begitu juga dengan konseli DN dan SH yang jarang mau menuruti perintah orangtuanya karena sedang asyik sendiri. Konseli SH temasuk pribadi yang pendiam begitu juga didukung dengan pendapat guru di sekolahnya, SH selalu menjawab ketika ditanya, jadi dalam proses konseling dengan konseli SH selalu melalui pendekatan yang cukup lama terlebih dahulu sampai konseli SH terbuka dan nyaman.

Peneliti menyadari dalam pelaksanaan konseling dibutuhkan waktu yang lebih banyak untuk sesi latihan konseli, tapi karena dibatasi waktu dan tempat yang tidak kondusif, itu adalah salah satu faktor kesulitan dalam mengungkap lebih dalam masalah yang dihadapi konseli SH karena pada dasarnya konseli SH termasuk pribadi yang pendiam dan pemalu. Berbeda dengan konseli SH, konseli JT dan DN cukup terbuka dan aktif dalam proses konseling, JT terlihat lebih cepat merasa nyaman dengan konselor dan terbuka. Begitu juga dengan konseli DN, konseli lebih terbuka dan mempunyai kepribadian yang ceria dan aktif sehingga konselor mudah memahami dan menggali masalah yang terdapat dalam diri konseli. Penelitian ini menggunakan alat ukur angket dan wawancara, angket diisi konseli setelah selesai sesi konseling. Walaupun setiap angket yang sama konseli terlihat serius dalam mengisi angket, dibaca setiap butir dan dengan waktu yang cukup lama. Wawancara juga digunakan penelitia sebagai alat ukur kepada guru pendamping, dan kepada siswa yang sekelas dengan konseli, setelah sesi konseling berakhir kemajuan apa saja yang dilihat lingkungan kepada konseli.

Hasil penelitian terbukti efektif untuk mengembangkan kekuatan karakter kesederhanaan, hal tersebut dapat dilihat adanya bukti konseli JT mampu bersikap lebih baik pada orang yang menyakitinya, mampu berteman dengan semua orang, mampu mengerjakan tugas lebih tepat waktu dan bisa lebih mengendalikan emosi. Konseli DN juga menjadi lebih baik dengan lebih bisa menghargai temannya begitu juga dengan SH yang sudah bisa lebih mengendalikan emosi ketika menemukan situasi yang tidak menyenangkan.

Hasil observasi dalam penelitian dapat disimpulkan konseli JT, DN dan SH mengikuti proses konseling dengan baik, sesi pertama konseling konseli JT, DN dan SH dalam kategori cukup, dalam sesi kedua, tiga dan empat konseli JT, DN dan SH dalam kategori baik, untuk konseli DN dan SH sesi ketiga dan keempat memiliki skor sama tetapi dengan aspek peningkatan yang berbeda dalam setiap sesi konseling.

Sejumlah penelitian mengenai teknik modeling simbolis efektif dalam meningkatkan aktivitas pembelajaran pada siswa kelas V SD (Astutik, 2007). Begitu juga dengan penelitian (Sulistiana, 2014) teknik modeling simbolis dapat menigkatkan kepercayaan diri siswa. Temuan ini meberikan penguatan bahwa konseling individu dengan teknik modeling simbolis memberikan dampak yang positif dalam membantu permasalahan peserta didik.

\section{SIMPULAN DAN SARAN}

Hasil penelitian konseling individu dengan taknik modeling simbolis untuk mengembangkan kekuatan karakter kesederhanaan (temperance) diperoleh kesimpulan sebagai berikut:

1. Gambaran kekuatan karakter kesederhanaan (temperance) siswa kelas XI SMK Vijaya Kusuma secara rata-rata memiliki kekuatan karakter kesederhanaan (temperance) pada kategori sedang.

2. Intervensi yang telah diberikan hasilnya dapat disimpulkan bahwa konseling Individu dengan teknik modeling efektif mengembangkan kekuatan karakter kesederhanaan. Hasil evaluasi dengan melakukan wawancara dan diberikan angket kembali untuk mengukur kekuatan karakter kesederhaan, dan wawancara hasil pengamatan guru dengan teman konseli hasilnya menunjukan bahwa konseli merasakan perubahan mengembangkan kekuatan karakter kesederhanaan. Berdasarkan uji empirik, dapat disimpulkan konseling individu dengan teknik modeling simbolis secara umum efektif untuk mengembangkan kekuatan karakter kesederhanaan siswa kelas XI Vijaya Kusuma. Konseling individu dengan teknik modeling simbolis efektif mengembangkan kekuatan karakter kesederhanaan tiga siswa subjek penelitian pada semua sapek kekuatan karakter 
kesederhanaan yaitu pengampunan dan belas kasihan, rendah hati, bijaksana dan bisa mengotrol diri.

Berdasarkan kesimpulan, maka saran penelitian ditujukan konselor (guru BK) dan bagi peneliti selanjutnya. Rekomendasi bagi konselor dan peneliti selanjutnya, perlu mulai menggunakan konseling individu dengan teknik modeling simbolis untuk membantu peserta didik menyelesaikan masalah yang dihadapi, khususnya yang terkait dengan mengembangkan kekuatan karakter kesederhanaan. Serta meneliti kekuatan karakter kesederhanaan dengan berbagai jenjang pendidikan dengan metode dan pendekatan yang berbeda disesuaikan dengan keadaan peserta didik masing-masing.

\section{DAFTAR RUJUKAN}

Ali, M., \& Asrori, M. (2009). Psikologi Remaja (Perkembangan Peserta Didik). Jakarta: Bumi Aksara.

Alwisol, M. (2007). Psikologi Kepribadian. Malang: Universitas Muhammyadiah Malang.

Arumsari, C. (2018). Kekuatan Karakter dan Kebajikan dalam Bimbingan dan Konseling. Journal of Innovative Counseling: Theory, Practice, and Research, 2(1), 1-5.

Astutik, E. (2007). Efektifitas Teknik Modeling Simbolis dalam Meningkatkan Aktivitas Pembelajaran Pada Siswa Kelas V SDN Sekaran 01 Gunungpati. Universitas Negeri Semarang, Semarang.

Creswell, J. W., \& Creswell, J. D. (2017). Research design: Qualitative, Quantitative, and Mixed Methods Approaches. Los Angeles: Sage Publications Inc.

Lestari, I. (2015). Pengembangan Layanan Informasi Teknik Symbolic Model Dalam Membantu Mengembangkan Kemandirian Belajaranak Usia Sekolah Dasar. Jurnal Konseling GUSJIGANG, 1(1).

Mamarodi, R. S. (2015). Kurikulum Pendidikan Agama Kristen (PAK) di Sekolah Menengah Atas (SMA) dalam Kajian Pendidikan Karakter. Universitas Kristen Satya Wacana,

Mulyasa, E. (2011). Manajemen Pendidikan Karakter. Jakarta: Bumi Aksara.

Niemiec, R. M., \& Clyman, J. (2009). Temperance: The Quiet Virtue Finds a Home. PsycCRITIQUES, 54(46).

Nursalim, M. (2005). Strategi Konseling. Surabaya: Unesa University Press.

Peterson, C., \& Seligman, M. E. (2004). Character strengths and virtues: A handbook and classification (Vol. 1). Oxford: Oxford University Press.

Sa'ud, U. S. (2007). Modul Metode Penelitian Pendidikan Dasar. Bandung: Universitas Pendidikan Indonesia.

Said, N. (2016). Buku dan Rumah Berjendela Dunia (Gerakan Rekreasi di Perpustakaan Keluarga). LIBRARIA: Jurnal Perpustakaan, 2(2), 41-57.

Sukardi. (2003). Metodologi Penelitian Pendidikan. Jakarta: Bumi Aksara.

Sulistiana, Y. C. (2014). Upaya Meningkatkan Kepercayaan Diri Siswa Melalui Layanan Konseling Kelompok dengan Teknik Modelling Simbolik Tahun Pelajaran 2013/2014. Universitas Muria Kudus, Kudus.

Toner, E., Haslam, N., Robinson, J., \& Williams, P. (2012). Character strengths and wellbeing in adolescence: Structure and correlates of the Values in Action Inventory of Strengths for Children. Personality and Individual Differences, 52(5), 637-642.

Usman, I., Puluhulawa, M., \& Smith, M. B. (2017). Teknik Modeling Simbolis dalam Layanan Bimbingan dan Konseling. Paper presented at the Proceeding Seminar dan Lokakarya Nasional Bimbingan dan Konseling 2017.

Willis, S. S. (2010). Konseling Individual Teori dan Praktek. Bandung: Alfabeta. 